Годищњак Филозофског̄ факулиеиейа у Новом Саду, Къиг̄a ХХХVIII (2013)

Annual Review of the Faculty of Philosophy, Novi Sad, Volume XXXVIII (2013)

Bence Erika

Filozofski fakultet Univerziteta u Novom Sadu

UDC: $821.511 .141: 82-24$ "18"

Originalni naučni rad

\title{
A BÁNK BÁN ÉS A MIC BÁN-MONDA KÉRDÉSE*
}

Történeti-poétikai, monografikus, forrás- és folklórkutatások hatalmas tárháza kapcsolódik a magyar irodalom klasszikus drámai müvéhez, Katona József Bánk bánjához. Jelentőségét és összetett jelentéssturktúráját jelzi, hogy majdnem kétszáz évnyi távlatból is megszólíthatók dilemmái, feltehetők értelmezésének mindmáig vitatott és teljességében megválaszolatlan kérdései, vizsgálhatók megértési hiátusai. Jelen kutatásunk a Katona-dráma - az irodalmi recepció által elnagyoltan tárgyalt, és dramaturgiai okok miatt elhibázottnak tartott, ún. Mic bán-epizódját vizsgálja több vonatkozó diszciplína - az irodalomtörténeti távlat mellett a kulturális antropológiai szempont beiktatásával. A vizsgálat célja nem lehet a drámához kapcsolódó korszakos problémák megoldása, ugyanakkor feltételezhetö, hogy az interdiszciplináris megközelítés közelebb visz néhány jelentés megértéséhez (pl. a jelenet beiktatásának funkciója, Simon bán hét ikerfiáról szóló elbeszélésének hitelessége, a hetes szám problematikája).

Kulcsszavak: Mic bánné mondája, európai folklór irodalom, mitikus tudat, létszámfölöttiség, eredetmonda

\section{Simon bán alakjának történeti forrásai és kutatása}

A Simon bán-Mic bán ${ }^{1}$ analógiára, azaz a bojóthi Mortundorfok Simon és a mondabeli Mic bán azonosságára maga Katona József hivatkozik a Bánk bán 1819-es változatához írt Jegyzésében: „Azután akadtt egy Iromány is előmbe, mellyben az van, hogy Michael és Simeon Micz-bán Spanyol Testvéreknek volt egy világszerte híres szépségű Húgok, kit Benedictus-(Bánk-)bán, Konrád Grófnak a' fia vett el” (Bbán Krk., 1983:155-156). A forráskutatások (Pór 1890; Tolnai, 1918; Badics, 1925; Waldapfel, 1931) feltárták, hogy ez az „Iromány” Kézai Simon Gesta Hungarorumának Appendixe (1282-1283) volt, illetve lehetett. $1782^{2}$-ben

erikazambo@eunet.rs

A név írásmódja a korszak helyesírási normáitól függően változó: Mitz bán, Micz bán, Micz-bán, Micbán, Mic bán, Simon Micbán etc. alakban fordul elő. Saját szövegemben a 20. század második felében gyakorlattá vált Mic bán-írásmódot alkalmazom, kivéve a régi, vagy idegen nyelvü szövegekre történő hivatkozásokban és az ezekböl vett idézetekben, ahol meghagytam az eredeti írásmódot.

2 A Bánk bán 1983-ban, Orosz László gondozásában napvilágot látott kritikai kiadása szerint Bécsben 1781-ben, Budán pedig a következő évben jelent meg Kézai Simon Gesta Hungaroruma: mindkettő Horányi Elek kiadásában. M. Simonis de Keza Chronicon Haungaricum. Excitat Alexius Horányi. 2. editio. Budae, 1782 . 
jelent meg nyomtatásban Bécsben, majd ugyanebben az évben Budán is Horányi Elek kiadásában.

A Kézai-gesta, a korábbról már ismert Thuróczy-krónika ${ }^{3}$, Katona István Historica critica regnum Hungarie 4 (1779-1817) címü forrásgyüjteménye, valamint a - Bánk bán első változata elkészültének évében, 1815-ben Lipcsében megjelent, a második változat létrehozása idején már forrásként alkalmazott - Die Geschichte der Ungern und ihrer Landsassen I-II. ${ }^{5}$, Ignacius Aurelius Fessler [Fessler Ignác Aurél] müve vonatkozó utalásai alapján gondolja azonosnak - az idézett forráskutatások szerint: tévesen - Katona a bojóti Simon bánt a Mic bán-történet Simonjával. Tolnai Vilmos szerint ennek alapja az lehetett, hogy Kézai Simon „spanyolnak mondja a testvéreket” (Tolnai, 1918: 5) Gestájában: „Comites Simon, et Michaël Hispani.” (Kézai, App.: 16.§), ugyanakkor Fessler „der Spanier Graf Simon"-ként (Fessler, 1833: II. 840) nevezi meg a Mic bán-történet Simonját. Ez a magyarázata annak is, hogy a Bánk bán első fogalmazásában Simon és Mikhál bán nem - az akkor még Adelájd néven szereplő - Melinda testvérbátyjai, sőt, a Mic bán-epizód is teljes egészében hiányzik a drámából. Tolnai szerint a dolog igazi paradoxona az, hogy maga Fessler egyszer sem tárgyalja egyként a két Simon bán történetét. A kritikai kiadásban ugyanakkor van utalás arra vonatkozóan, hogy Fessler szövegében „találhatott alapot Katona” az azonosításhoz (Bbán Krk. 1983: 435).

A Jegyzésben említett „Iromány” egyes forráskutatók (Pór, 1890; Badics, 1825; Waldapfel, 1831) szerint lehetett II. András 1221-ben kelt adománylevele is, amelyben egy bizonyos „Korláth fia Benedek vajda feleségének, a spanyol származású Tota asszonynak elkobzott birtokait adja vissza" (Bbán Krk., 1983: 431). Katona teljes mértékben azonosnak véli a Benedictus/Benedek néven nevezett Korláth/Konrád fiát Bánkkal, miként Tota asszonyt Melinda alakjában formázza meg; az összevető vizsgálatok arra mutatnak, hogy Katona nem az adománylevél (még ha ismerhette is Horváth István révén, aki a Nemzeti Múzeum öre volt, s felhívhatta figyelmét az ott őrzött másolatra), hanem a Kézai-krónikában talált adatok alapján gondolta érvényesnek ezeket a személyi megfeleléseket. Természetesen a történeti kutatások e kérdésben is eltérő eredményre jutottak: az adománylevélben említett Tota asszony férje, Benedictus Dux nem azonos Bánk bánnal: Érdújhelyi Menyhért (Érdujhelyi, 1893: 34-41) szerint arról a Benedek hercegről van szó, aki Halics kormányzója volt a XIII. század vonatkozó évtizedében. „Az 1221-i oklevél is szól arról, hogy Tota Constantia királynéval jött Magyarországra, s feleségül ment Korláth [!] fia Benedek herceghez. Szépségét azonban az oklevél szövege nem említi. A Katonától kiemelt valamennyi adat együtt van viszont Kézai Krónikájának Appendixében, s Benedictust ott nem

\footnotetext{
Chronicon Hungarorum, Augsburg, 1488. Katona József a Thuróczy-krónika Schwandtner Scriptores rerum Hungaricarumában megjelent kiadására (Schwandtner, J. G. [1765]). Scriptores rerum Hungaricarum veteres ac genuini. Cura et studio J. G. Schwandtneri. I-III. Wien) hivatkozik az első változat V. felvonásának egyik jegyzetében. (Bbán Krk., 1983: 135).

Katona, Stephanus (1779-1817). Historia critica regum Hungariae. T. I- XLII. Pest at al.

Fessler, I. A. (1815). Die Geschichte der Ungern und ihrer Landsassen I-II. Leipzig: Joh. Friedr. Gleditsch
} 
Korláth, hanem Katona szövegének megfelelően Konrád fia. Már ez is valószínüsíti, hogy ezt olvasta Katona, ezt nevezte Jegyzésében a kérdéses »Iromány«-nak" (Bbán Krk., 1983: 432).

A Bánk bán kritikai kiadása ugyancsak körüljárja a Simon bán-Mic bán-azonosság kérdését azzal, hogy nemcsak a Gertrudis királyné elleni összeesküvésben részes Simon (Bánk bán feleségének testvére), illetve a Mic bán-történet Simonjának egy és ugyanazon személy voltát, de a Spanyolországból bevándorolt Murtondorfok nemzetségbeli Simon velük való azonosságát is vitatja. A feltárt források alapján arra következtethetünk, hogy Katona három 13. században élt valós személyből „gyúrta eggyé” a drámabeli Simon alakját. Az egyik a Murtondorfok [Mertinsdorff ${ }^{6}$, Mortundorff ${ }^{7}$ ] nemzetségből származó és Spanyolországból menekült Simon (vagy két/több Simon) alakja. A forráskutatások a Kézai-krónika függelékének következő részletét emelik ki:

„Comites Simon, et Michaël Hispani. Comitum vero Simonis, et fratres eius Michaëlis generatio, qui Mertinsdorffarii nominatur, filia Regis Aragonie, que uxor erat Regis Emrici ... in Hungarian pomposissime introiut ... Quia vero generatio saepedicta [olv. Supradicta] in regno Ispanie plura Castra possidet, vnum tamen ex illis existit capitale, quod Bojot nominatur. Vnde praeferati Comites... primum descemsum circa Nergedseg [= Nyergesújfalu Esztergom megyében] Bojot vocauerunt. [ma Bojót $\mathrm{u}$. ott]. Generatio quoque eorundem in Scuto Aquilam ferre solet, quam alii Milites, Comites in Ispania deferre non praesumunt. ... Adduxerat etiam Regina Constantia cum ea Sororem Comitis Simonis ... nomine Totam tam formosam, et pulcherrimam, quod eo tempore vix in Mundo sibil similis haberetur. Cui quidem virgini in maritum Benedictus Dux Conradi filius, cum villa Mertinsdorff, pro dotibus ex parte Emerici Regis, et Reginae Constantia est coninctus" (Tolnai, 1918: 6.; Bbán Krk, 1983: 434-435) .

\footnotetext{
Kézai Simon Gesta Hungarorumában szerepel.

A Thuróczy-krónikában fordul elö a névnek ez az alakja.

Szabó Károly fordításában: „Simon gróf és testvére Mihály nemzetsége pedig kiket Martinsdorferek-nek hívnak, harmadik Béla király fia Imre király idejében Constantia királynéval, az arragoniai király leányával, ki Imre király felesége vala, jött bé Magyarországba magokkal becsületes vitézeket és igen díszes kíséretet hozván. Mivel ugyanis nemzetségök bizonyos nagy gróffal igazságos és bizony okokért folytonosan harczolt, végre azon gróf ellen, mint mondják, sereget gyüjtve hadakozott, mikor az említett nagy grófot Simon, t. i. Simon és Mihály gróf atyja, és nagybátyja Bertrám elfogván megölte. Miért is Simon és Bertrám ellenségeskedést vonván magokra, az emlitett királynéval mindjárt bejönnek Magyarországba. Kiknek nemes voltukat tapasztalván Imre király, örömmel fogadá őket s széles és bő hủbéri jószágokkal adományozá meg Magyarország különböző részeiben. Mivel pedig az emlegetett nemzetség Spanyolországban több várat bir, melylyekben azonban egy Bojót nevü a fő: azért is az említett grófok és elődeik legelső szállásukat Nyergedszeg körül Bojótnak nevezték. Nemzetségök sast szokott pajzsán viselni, mellyet más vitézek és grófok Spanyolországban hordani nem bátorkodnak, még pedig azért, mert a tunisi szultán seregét, melly Majorika és Minorika szigetét hajókkal és hajós sereggel megszállva elfoglalta volt, az arragoniai király többi vitézei nem birván, mint mondják, az ő nemzetségök verte ki. A honnan a király és a vitézek községének végzéséböl határozva lőn, hogy elöbbi czimeröket, melly írott alak nélkül tiszta vörös vala, sassal cseréljék föl. Elhozta volt Constantia királyné magával Simon és Bertrám gróf Tata nevezetủ hugát is, olly szép és gyönyörü leányt, hogy azon időben a világon hozzá hasonlót alig tartanak vala. Melly leány Benedek herczeggel, Konrád fiával, kelt egybe, Martinsdorf faluval együtt más jegyajándékokat is kapván Imre király és Constantia királyné részéről.” (KÉZAI, é. n., Függelék, 16. §)
} 
A kritikai kiadás idézett történeti forrás-elemzésében a Thuróczy-krónika vonatkozó kitételei alapján az a megállapítás nyer érvényt, hogy az a Simon bán, aki részt vesz a Gertrudis királyné elleni merényletben [s aki a drámában Mikhál öccse, $\mathrm{s}$ annak a Melindának a bátyja, aki a forráskutatás alapján mégsem lehet azonos Benedictus herceg Tota nevü feleségével, miként Benedictus Dux sem Bánkkal] nem lehet azonos a spanyolországi „,beköltözött” Simonnal sem, sem azzal a Simonnal, akinek a bátyja Michaël volt. A Constantia királynéval érkezett Simon testvérét ugyanis Bertramnak hívták, „a Simon és Mihály testvérpár már a következő nemzedék lehet: [Katona] a Bánk bánban szereplő testvéreket a beköltözöttekkel veszi azonosnak" (Bbán Krk., 1983. 434). Ök viszont még nem voltak Magyarországon a merénylet idején, csak később, András király fiának, IV. Bélának az uralkodása alatt érkeztek. Ugyanakkor: ha figyelmen kívül hagyjuk Érdujhelyi Menyhért véleményét, aki kizárja, hogy Benedictus Dux azonos lenne Bánkkal, s úgy véljük, miként Thuróczy, illetve Katona József, hogy a király 1221-es adománylevelében emlegetett férji hütlenség (király elleni összeesküvés) a királyné elleni merényletet jelenti, akkor viszont a dráma Melindára vonatkozó részletének nincs történelmi hitele - az adománylevél ugyanis egyértelmüsíti, hogy Tota asszonynak a férji esküszegés következtében sem lett semmilyen testi bántódása, sőt elkobzott vagyonát is - a királynéhoz [II. Andres második feleségéhez] való rendíthetetlen hüsége jutalmául - maga II. András adja vissza - megtiltva még az „ellene esetleg felmerülő” (Uo.: 432) gyalázkodásokat is.

Feltételezhetjük, hogy a merényletben részes Simon testvérét nem Mihaëlnek hívták, hanem Bertramnak. Joggal hihetjük azonban - s ebben II. Andrásnak egy másik, 1228-ban kelt, Simon vagyonának elkobzásáról szóló oklevele erősít meg bennünket -, hogy egy Simon bán, akinek Mihaelis volt a testvére, mégis részt vett a Gertrudis elleni merényletben, arra azonban nincs adat, hogy lett volna Tota nevü húguk. Valószínübbbnek tủnik, hogy a merényletben részes föurak csoportjában több Simon bán is volt. A történeti források és a történeti forráskutatások sem szolgálnak ugyanakkor semmilyen bizonyítható adattal arra vonatkozóan, hogy Benedictus/Bánk feleségét bármilyen - a királyné megöletését kiváltó - erkölcstelen merénylet érte volna, vagy, hogy a királyné bármelyik öccse eltervezte házasságtörés közvetlen kiváltó oka lett volna Gertrudis megöletésének. Meggyőződésem szerint ezek az összefonódások a történetírás mindenkori - de különösen a középkori krónikaírásra érvényes - „fikcionális természeté”-ből következnek (White, 1997).

Két dolgot azonban biztosan tudunk: II. András első feleségét, Merániai Gertrúdot [németül: Gertrud von Andechs-Meran] 1213. szeptember 28-án a pilisi erdőben megölték, s hogy ebben a merényletben legalább egy Simon bán, akinek Michaelis nevü testvére volt, részt vett. Azt viszont Tolnai Vilmos meggyőződéssel és bizonyosnak tekinthető források alapján állítja idézett, 1918-as forrástanulmányában, hogy ez a Simon bán semmiképp sem lehet azonos Mic bánnal, $\mathrm{s}$ hogy ez az elem (A Mic bán-történet elbeszélése az I. felvonás első jelenetében) Fessler történeti munkájának hatására került Katona József Bánk bán címü drá- 
májába. Erre vonatkozóan a következő (forrás)adatokat emeli ki: Katona a dráma első változatát 1815. július 30-án fejezte be, Fessler történeti munkájának két kötete - kiadójának jogutódja ${ }^{9}$ biztosította az adat pontosságát - 1815. szeptember 30. és október 10. között jelent meg, tehát a drámaíró csak a második változat kidolgozásához használta történeti forrásként. Időközben kezébe került a Kézai-krónika („Iromány”) valamely kiadása is - feltehetően az 1782-es budai -, amelyben adatot talált Simon és Mikhál bán spanyol származására vonatkozóan, miként Fessler munkájában Mic bán spanyol gróf mivoltára. A két hivatkozást összevonva alkotta meg - a korábban használt források adataival együtt - a spanyol származású, Constantia királynéval Magyarországra érkezett, a Gertrudis megölésében részes Simon bán alakját, aki e formában Melinda testvérbátyja és Simon Micbán ${ }^{10}$, azaz a mondában szereplő hét ikerfiú apja. A vonatkozó kutatások (Tolnai 1918; Csikós 1993) szerint a drámában szereplő Simon bán nem lehet az a személy, akit Fessler hétgyermekes spanyol grófnak, azaz Simon Micbánnak nevez, mivel a merényletben részes Simon bán - az idézett 1228-as királyi oklevél bizonyítja javait elkobozták, $s$ ha nem is végezték ki, bizonyára számüzték, bujdosott, sőt nem kizárt, hogy mégis áldozatul esett a később is, így a IV. Béla idejében történt megtorlásoknak. „Miczbán Simon 1242-ben hősieskedik a tatárral szemben, neve »Graf Simon«, s fia 1285-ben királyi adományt kap" (Tolnai, 1918: 5). Csikós Zsuzsa (Csikós, 1993) szerint nincs történelmi alapja a Simon bán-Mic bán analógiának: a Mic bán-történet egy olyan európai mondatípus változata, amely nemzetségek eredetmondájaként lokalizálódott - de az eredetet Simon comes hét ikerfiának történetével összekapcsoló Bocskai család mondája csak egyike a magyar nyelvterületen létező, s az adott őst megnevező családi legendáknak.

\section{A Mic bán-monda kulturális antropológiai vonatkozásai}

A Mic bán monda több diszciplínát érintő európai kiterjedésű kutatástörténetet jelent: a történet-, a földrajz-, az irodalomtudomány, a folklórkutatás különböző ágazatai foglalkoznak változataival és kérdéseivel; ma antropológiai, szociológiai, pszichológiai vetületei is érdekesek lehetnek, de az orvostudomány álláspontja is értelmezési alapmozzanatként kezelhető.

A Mic bán történet (vagy: Mic bánné mondája) az európai „mondaáramlat” (Heller, 1909: 72) összefüggésrendszerében értelmezhető: német, spanyol, francia, lengyel változatai ismertek, de visszavezethető az ókori mitológiai alapú világ- illetve eredetmagyarázat jelenségeire, illetve a nemzet születéséről szóló eposzi hagyományra (pl. Romulus és Remus legendája). A nyugat-európai és a magyar hagyományban is nemzetségek eredetmondájaként lokalizálódtak változatai, ezek közül legismertebbek a sváb Welf-monda ${ }^{11}$, magyar nyelvterületen a Bocskai család

\footnotetext{
9 Joh. Friedr. Gleditsch jogutódja F. A. Brockhaus.

10 „Der Spanier Graf Simon, wahrscheinlich Mitzban, durch eine einzige Entbindung seiner Gemahlin Vater von sieben Söhnen" (Fessler, 1815. II. 539; Tolnai, 1918: 4).

11 „Altorf grófnéja, Irmentrud házasságtörőnek nevez egy hármas ikreket szülő szegény asszonyt, s ezután neki egyszerre tizenkét fia lesz. Közülük egyet megtart, a többit kádba rakatja, és egy öreganyóra parancsol,
} 
eredetmondája, miközben számos más európai (és magyar, pl. a Sóvári Soós) nemzetség „tart igényt” - miként Csikós Zsuzsanna fogalmaz tanulmányában (Csikós, 1993: 83) - a Mic bán-mondára, mint a család származását igazoló ősmondára. Csikós épp ennek alapján, vagyis a változatképződés, illetve a mesei átalakulás (a népmesekutatás ugyanis legalább három olyan meseváltozatot ismer, amelyben ez a mondai elem érhető tetten) jelensége okán tartja érvénytelennek a Mic bán-mondához történelmi hitelességet kapcsoló interpretációkat (Uo.: 79).

Miként az európai irodalomban, a magyarban is számos irodalmi feldolgozása ismert; feltárták első szövegelőfordulásait. Német, illetve normann területeken a 12. századi írónő, Marie de France Fraisne címü novelláját tartják kiinduló irodalmi változatképződési mozzanatnak (Heller, 1909: 70), míg nálunk Szamosközy István, Bocskai István történetírója 1604-ben tett feljegyzése töltötte volna be ugyanezt a szerepet, ha ismeretlensége miatt nem marad hatástalan mintegy három évszázadon át. Sokkal valószínübb, hogy a Mic bán-monda irodalmi elterjedésében a protestáns prédikációirodalom volt mérvadó, mindenekelőtt Alvinczi Péter 1622-ben, Károlyi Zsuzsanna fejedelemné temetésén mondott gyászbeszéde, amelyben a Mic bán-történet oktató jellegü betéttörténetként szerepel.

Jelen dolgozatunkban eltekintünk a Mic bán-mondához kapcsolódó rendkívül kiterjedt interdiszciplináris kutatások történetének és eredményeinek feltárásától, ezekből csak azokat a mozzanatokat emeljük ki, amelyek interpretációnk tárgya - a Mic bán-történet értelemzése Katona József Bánk bán címü drámájában szempontjából fontosak lehetnek.

Miként a kérdés 20. század eleji kutatója, Heller Bernát kiemeli, a Mic bán-történet lényege - „veleje” (Uo.: 70) -, hogy „Nő házasságtöréssel vádol más nőt, néha parasztasszonyt, néha előkelő nőt, mert ikrei vannak; nemsokára maga is világra hoz, a különböző változatok szerint 2, 3, 7, 9, 12, 13, sőt 365 gyermeket. Magyar irodalmunkban Dugonics két, a Micbán-monda hét, a sajóvölgyi mese kilenc, egy biharmegyei mese tizenkét gyermekről szól" (Uo.). Kilenc évtizeddel később keletkezett, idézett tanulmányában Csikós ehhez a szüzséhez részben születésstatisztikai összefüggéseket, másrészt a népi kultúra fogamzáshoz/születéshez/ szüléshez kapcsolódó szokásait, hiedelmeit kapcsolja magyarázatként:

„A folklór-szakirodalom öt mesét rokonít a hét ikerfiúról szóló elbeszéléssel, s ezek mindegyikében ikerellenes népies szemlélet mutatkozik meg. Az ikerellenes szemlélet az ikerszülések ritkaságával, különleges voltával magyarázható. A babona szerint annak az asszonynak születhet egyszerre több gyermeke, aki összenőtt kettős gyümölcsöt vagy kettős spárgájú tojást eszik, mással egy törölközőt használ, vagy akinek gyermekei nem egy apától származnak. Így azután érthető, hogy az ikerszülést igen szégyenletes dolognak tartották és elítélték” (Csikós, 1993: 79).

\footnotetext{
hogy fojtsa a gyermekeket patakba. Az öreganyó szembetalálkozik Isembarttal, Irmentrud férjével, és amikor Isembart megkérdezi tőle, mit visz a patak felé, azt hazudja: kutyakölyköket. (A monda szerint a Welfek nemzetsége épp innen nyerte nevét.) Isembartnak gyanúja támad, miszerint az öreganyó nem mond igazat, ezért megnézi a kádat, és leleplezi a hazugságot. A gyermekeket azután a környékbeli gazdag molnárral nevelteti fel, majd hatéves korukban Irmentrud elé vezeti őket. A történet itt is megbocsájtással végződik, s azzal a megállapítással, hogy ez a tizenkét fiú a Welf nemzetség őse" (Csikós, 1993: 83).
} 
Ugyanő idézi - a Mic bán-történet alapját képező szemlélettel kapcsolatban - Dugonics András Etelka címü regényének Etelka születésére vonatkozó részleteit, amelyben az ikerszülés ugyancsak erkölcstelen életvitellel összefonódó jelenség: „Eszébe jutottak (a' Fejedelemnőnek) Árpád' szavai, melyekkel élt az olyatén szeméjek ellen, ki egy hassal két gyerököt pottyantanak. Ezeket ö félre-farlóknak, félre-billentőknek; azaz jámbortalan-életű cinduláknak lönni állította" (Dugonics, 1788: 263-264). Az elmesélt történethez Dugonics a későbbi századok közfelfogását minősítő megjegyzést („,ez a vélekedés a’ követközött Magyaroknál-is fen-tartatott" [Uo.]) füz, és lábjegyzetben meséli el Alvinczi Péter prédikációjának Mic bán- mondát elbeszélő részletét (Uo.).

A terhességhez és a szüléshez kapcsolódó hiedelmeket Balázs Lajos (Balázs 2012: 96) a népi magzatvédelmi kultúra részének tekinti, s bennük nem a babonás tudáselemeket, hanem a születés előtti élet védelmére kialakított preventív - etikai vonzatokat is felvető - eljárásrendszert lát. A terhes nő viselkedését meghatározó tilalmak rendszerét szellemesen a népi kultúra szellemi „ekográf készülék”-ének nevezi:

„A tudomány, a prenatális medicina - amely a 60-as évek Amerikájában jött létre -, fogalmazta meg a prenatális állapot, az intrauterin élet azon lényegét, amit a csíkszentdomokosi mágikus müveltség ösztönösen, tapasztalati alapon több évszázada felismert, és hagyományos kultúrájában hiedelemként rögzített. De ez a hiedelemvilág képes volt arra, hogy válaszokat adjon azokra a kérdésekre, amelyeket a magas civilizáció világában a müszerezett és szintén jelekből élő orvosi rendelőkben keresünk. [...] A népi múveltség ráérzéseivel, tapasztalatával »felfedezte« azt, amit a prenatális medicina a 20. század második felében fedezett fel: hogy az anya és magzata között, hogy a magzat és környezete között organikus kapcsolat létezik, müködik és ebben az anya a mediátor. Ennek a felismerésnek az alapján a két műveltség más-más szemszögből közelítette meg a prenatális állapotot: az orvostudomány, a pszichológia a pozitív stimulációt követi: a zenehallgatás, meditáció, az anya hangjának benefikus hatásáról hallok, olvasok. A népi prenatális kultúra pedig a rossz prevenciójára összpontosít. Ezt részben azzal magyarázom, hogy a paraszti kultúrának évszázadok óta kiforrott embereszménye van, amit egész szellemiségével védelmez. A parasztasszony nem tudott tételes elméleti ok és okozati összefüggéseket megfogalmazni, de a kihordás ideje alatt a tiltások, intelmek rendszere szerint volt köteles élni, és élt" (Uo.: 96).

Ez a fajta viselkedéskultúra „kialakította a felelős anya lelkivilágát” (Uo.: 97). A 13. században a terhes nőnek társadalmi helyzetétől függetlenül - akár foúri feleség, akár parasztasszony volt - nem állt rendelkezésére e preventív tudás-/ hiedelem-/tilalomvilág tapasztalatain kívül más eljárásmód, amellyel a szép és egészséges gyermek születését biztosíthatta volna; e tiltásokon alapuló erkölcsi rend szerint kellett élnie. A nem egészséges, nem szép, vagy rendellenes utódok (pl. ikrek) világrahozatala ennek az etikai kódexnek a megsértésével volt összefüggésbe hozható. Mic bánné a preventív erkölcsi viselkedéskultúra több tilalmát is megszegte, amikor csúnyán beszélt, koldusasszonyt utasított el (egyes változatok szerint az elveszejtésére szólított fel!) és vádolt meg erkölcstelenséggel: „Csúnyát a terhes ne beszéljen, me a se jó a gyermekre nézve" (Uo.: 93). 
Orvosi szempontból ma is kockázatos lehet, a korai századokban pedig mind a szülő nő, mind a gyermekek szempontjából tragikus következményekkel járhatott az ikerszülés - közvetetten (az anya halála miatt) az egész család (nemzetség) fennmaradását veszélyeztethette. Nem célom túlbecsülni a (népi) kultúra tapasztalaton alapuló őstudását, de - miként azt Balázs Lajos is hangsúlyozza idézett tanulmányában - a mai orvostudományban kockázati tényezőként ismert jelenségek ismerete, természetszerüleg más nyelven - hiedelmekbe kódoltan -, de ott van a népi magzatvédelmi kultúrában is: „Tartózkodjunk [...] a kutya, macska érintésétől, mert ürülékükben, valamit a nyers húsban előfordulhat egy citoplazma nevü élősködő, mely súlyosan károsítja a magzatot" (Fenwick, 1993. 13); Balázs gyüjtésében: „,ne végy az öledbe kutyát, macskát, ne rúgj beléjük, mert szőrös lesz a gyermeked" (Balázs, 2012: 94-95). A néprajzkutató arra is kitér, hogy a tilalom megszegésének eseteit, a kivételeket a közösség (akár két generáción át is) megjegyzi, stigmatizálja, ami ezáltal viselkedéskultúrájának tapasztalati tudásalapjaként rögzül, hagyományozódik. A nemi erkölcs megsértése - a jelölt századok etikai szemlélete érvényében - minden más tekintetben is veszélyezteti a nemzetség létét, föbenjáró bün; az ikerterhesség e felfokozott védelmi rendben mindenkor következményként szerepel. Fontos mozzanat, hogy ez a gondolkodás nem ismeri a valószínüséget, a lehetőségek esélyeinek százalékszámítását, hanem mindenkor közvetlen következményekkel számol; aki megszegi a szabályokat, bünhődik - a nő, aki több férfival hál, ikergyermekeket hoz a világra. Az orvostudomány mai álláspontja szerint a két apától származó ikergyermekek születésének esélye egy az egymilliárdhoz - de lehetséges. (A világhálón követhető adatok szerint a dokumentált - és ma DNS vizsgálatokkal igazolható - esetek mindegyikében jelenvaló tényező, hogy az asszony 48 órán belül létesített két férfival szexuális kapcsolatot.)

A mitikus tudás más vonatkozásban is felmerül a mondatípussal kapcsolatban. Heller Bernát hívja fel a figyelmet arra, hogy a természeti népeknél még az újkorban is létező hiedelem szerint ,az egyen felüli gyermekek” (Heller, 1909: 73) gonosz szellemtől valók vagy emberfölötti lényektől származnak; a transzcendenssel (Heller szóhasználatában: istenivel) való állandó érintkezés pedig veszélyes a vele egy közösségben élökre. E néphit értelmében a második gyermeket vagy mindkettőt, esetenként az anyát is megölték. Az európai kultúrában elterjedt Mic bán-típusú monda annak az ősi tudásnak a nyomait őrzi, hogy az európai népek elötörténete is ismeri az ikergyermekek megölésének tettét, de ,a mondafaj akkor keletkezett, mikor a népérzés már föllázadt az ikergyilkosság ellen" (Uo.). Heller szerint ezt a mondatípust az Iphigenia-monda, illetve az Izsák föláldozásáról szóló bibliai történet vonzatkörében kell értelmeznünk, azt a tudást közvetíti, amely megfellebbezi, illetve kizárja azt a hitet, miszerint „az istenség a gyermeket kívánja áldozatul” (Uo.).

\section{A Bánk bán transzcendens tere}

Idegenek az éjszakában (Mikhál- és Simon-kommentárok) címủ tanulmányában Orbán László (Orbán, 2004: 97) megállapítja, hogy a filológiai kutatásokon túl a Bánk bán-értelmezések nem szentelnek nagy teret a „kínosan elhibázott 
beszúrásnak érzett" (Uo.) Mic bán-epizódnak. Valósak az általa idézett Waldapfel József megállapításai is, miszerint a kritika ,a bojóti Simonnal azonosított Mic bán hetes ikreiről szóló hagyományt [...] hibáztatták meseszerüsége miatt is, elbeszélésének a figyelmet a dráma kezdetén lekötö, a tulajdonképpeni cselekmény megindulását késleltető terjedelmessége miatt is; ez a drámának az a része, amelynek elhagyásában rendezői is leginkább egyetértettek" (Waldapfel, é. n.: 116; Orbán, 2004: 97). Heller Bernát „episodikus” résznek tartja a drámában, amelynek jelentése az a Mihálnak szánt üzenet, hogy „mint éled föl a Bojóthi Mortundorfok nemzetsége" (Heller, 1909: 68). Tolnai Vilmos, aki a Mic bán-történet elbeszélését a - fentebb tárgyalt - Fessler-hatásnak tartja, úgy véli, a történeti munkából - a korabeli szerzőségi feltételek mellett nem szokatlan eljárással - átmásolt epizód a dráma kontextusában iróniával telítődik, „épp akkor nyújt új reményt a számúzötteknek, épp akkor biztatja családjuk kiveszni induló ősi fáját új sarjakkal, mikor a következő órákban, szinte derült égből sújt rá a csapás" (Tolnai, 1918: 3). Ennek a tragikus iróniára épülö értésnek van számunkra egy olyan utalása, amelynek nyomán elindulva - ha nem is adhatunk kizárólagos választ a Mic bán-epizód drámabeli jelentéseire -, megnyithatunk egy új értelmezési szintet, Orbán László metaforájával élve, „rejtekajtót”12. A jelölt utalás a végzetszerüség, a fátum hatalmának jelenlétére vonatkozik a drámában. A fatálisnak ez a jelenléte egyrészt azzal a tudással áll összefüggésben, amely az előző részben tárgyalt mondateremtő öshitnek is a lényege - az ,egyen felüli gyermekek” kapcsolatban állnak a szellemi/isteni világgal -, másrészt arra vonatkozik, hogy a dráma „földi” cselekménye mellett egy vele együtt ható transzcendens életvilágban is történnek események, melyeknek törvényei nem minden esetben azonosak a reális világ képzeteivel, ugyanakkor vannak szereplők - mint Mikhál -, akik csak ebben a „másik világ”-ban élnek, illetve - mint Simon -, akik mindkettőben mozognak, s értik is mindkettő kódjait, szabályait. Az ,idegenek” Orbán László tanulmányában ezért nemcsak Simon és Mikhál bán idegen származására, hanem a reális világgal való különleges kapcsolatuk mibenlétére is utal, noha a tanulmányíró Tzvetan Todorov nyomán (Todorov, 2002) nem annyira a transzcendens, mint inkább a fantasztikum elötti „csoda” világaként értelmezi azt a szellemi teret, ahol a hét iker (a Mic bán történet) elbeszélést nyer:

„A hét iker elbeszélése - ha elhatároljuk a dráma szövegkörnyezetétől - egy családi eredetmítosz, amely azonban a Bánk bán »reális« világába jelen idejủ eseményként bekerülve elveszíti azt az időbeli távolságot, ami müfajisága létmódjához hozzátartozik. Simon és Mikhál nem, mint fikciót éli meg, hanem mint a »valóság« egy részét. Ha viszont a jelenkori olvasásmód - rekonstruálva az időbeliséget - »kétségeskedik«, akkor a mitikus és a történelmi kor találkozásánál a fantasztikum megjelenési helyeként és idejeként érzékelheti a hét iker történetét. Ez az epizód felfedheti azt a rejtekajtót, amelyen elhagyhatjuk a Palota »totális metaforá«-jába zárt különös, de reális világot, és ha úgy döntünk, átléphetünk a csodás világába” (Orbán, 2004: 99).

12 „A Bánk bán elsötétült, rejtekajtókkal átlyuggatott »mulató Palotá«-ja nemcsak a dráma rejtélyektől átszőtt cselekményének/beszédének kibontakozásához ad (metaforikus) teret, hanem a drámát megközelítő különböző értelmezések működési helyeként is funkcionálhat." (Orbán, 2004: 88) 
Akár a fantasztikum világaként értjük, akár a transzcendencia törvényeit érzékeljük a jelenet logikai/vagy logikátlan struktúrájában, a befogadóban először a hetes ikrek születésének ,hihetetlensége” vált ki reakciókat. A mai ember tényeken és tudományon alapuló tudása nem fogadja el a hetes ikrek születésének lehetőségét: ,[...] nemcsak azért vélhetjük csodának a hét fiút, mert mai ismereteink szerint nem születhetett és maradhatott életben hetes iker a 13. században, hanem - és föképpen - azért, mert egy (görög vagy ószövetségi) isten jelenlétét felfedő beavatkozás történt (»az Istenség adott hetet«). Simon felesége tragikus vétséget követett el, amikor erkölcstelennek nevezte és elkergette a koldusaszszonyt, »mert kettős szülöttye« volt” (Uo.: 102). Feltehetőleg a 13. század reális világában - ahol a Bánk bán cselekménye játszódik - sem volt hihető a hetes ikrek életben maradásának lehetősége, Simon és Mikhál azonban nem kételkednek; Simon mert látta a gyermekeket, Mikhált pedig biztosítja, hogy nem üz „,rút tréfá"-t vele. Orbán szerint ezt az isteni jelenlét-érzékelés teszi lehetővé:

„Mikhál, amikor elhiszi fivére elbeszélését, akkor a hit mozdulatát teszi meg: »csukott szemmel teljes bizalommal az abszurditás szakadékaiba« veti magát, és hisz a képtelenségben. Ugyanezt a mozdulatot figyelhetjük meg, amit Kierkegaard Ábrahám ősatya, a »hit lovagja« történetében csodál. Az idős Ábrahám az abszurd révén, vagyis a valószínűtlenen, a váratlanon és a kiszámíthatatlanon túl hisz abban, amit az értelem lehetetlennek állít. Vagyis abban, hogy habár ő és Sára is túl idős a gyermeknemzéshez, az mégis megtörténhet, mert Isten megígérte. [...] Mikhál a hét iker abszurd csodájában, ill. a hitben, hogy őket az Istenség adta - akárcsak Izsákot Ábrahámnak - a nemzetsége jövőjét kapta vissza" (Kierkegaard, 1986: 52; Orbán, 2004: 102).

Lehetséges azonban, hogy nem isteni, hanem egyfajta mitikus térbe kerülünk a „hetes ikrek” számának kimondásával. Mi több, igazából nem is hetes ikrekről, csak „egyen felüli gyerekek”-röl, a „létszámfelettiség” (Balázs, 2012: 332) problematikájáról van szó - a szám e kontextusban valójában lényegtelen: lehet a népköltészeti múfajok túlzás-alakzatáról (pl. a szegény ember gyerekeinek száma is képtelen hasonlattal fejeződik ki: ,mint a rosta lika”), de a hetes szám misztikájáról is szó lehet. Pócs Éva (Pócs, 2002: 65) és Balázs Lajos (Balázs, 2012: 332) egyaránt vizsgálja e jelenség rituális szimbolikáját. A néphit szerint ugyanis léteznek: „kirekesztett élők, kettős lények”, vagyis „státus nélküli élők” (emberből lett démonok): „törvénytelen kapcsolatból, harmadik, hetedik vagy kilencedik gyerekként születtek. Születésük hiedelmeit általában az osztályozatlanság, csoporton-kívüliség, időn kívüliség, létszámfelettiség szimbolikája veszi körül (ide tartozik a születésükkel kapcsolatos hármas, hetes, kilences szám)" (Uo.). Pócs Éva szerint a kirekesztettség oka lehet anyai átok, boszorkányság és varázslás vádja, de státus nélküliek a „,kitett gyerekek” is (Pócs, 2002: 65.). Simon Micbán hét fiának esete közvetlenül vagy közvetett módon, de az idézett mitikus tudás majdnem minden elemével összefügg: születésüket átok, a koldusasszony (ugyancsak ikrek anyja) átka és/vagy isteni büntetés váltotta ki, „létszámfelettiek"/"egyen felüli gyerekek" (akik lehetnek heten), anyjuk a törvénytelen kapcsolat gyanúja miatt (,„ne hogy / feslettnek ítéltessen” [Bbán Krk., 1983: 163]) tör a létükre, ,kitett 
gyerekek" lesznek, feltételezhetően - még - megkereszteletlenek, tehát a gonosznak hatalma van a néphit szerint felettük. Ebbe a folyamatba avatkozik bele Simon Micbán, amikor észrevéve - a monda változataitól függően - a rocskát/bocskát vagy kosarat a banya kezében, megtudva az igazságot, titokban nevelteti a gyerekeket, s felnőttként szándékozik majd visszaadni társadalmi státusukat, ami egyúttal az anya büne és bünhődése (,keservessen zokog, midőn / az egyjet a' kezébe vészi” [Uo. 164]) rituális feloldódású végét jelenti majd: „haljon-meg akkor - de örömébe haljon” (Uo.). Orbán László szerint ugyanakkor Simon bán is „,beavatkozik az isteni büntetés mechanizmusába" (Orbán, 2004: 102), tehát kivívja a gondviselés haragját, s nemcsak maga, hanem az egész bojóti nemzetség ellen. A dráma ezen értésmódja Melinda és Bánk tragédiáját a végzet hatalmával, az isteni eleve elrendeltségbe vetett hit megtagadása miatti büntetéssel hozza összefüggésbe: Simon Micbán felesége vétett az isteni törvények ellen, mert egy archaikusabb (nem keresztény) tudás szerint járt el, amikor a koldusasszonyt, mert „,kettős szülöttye volt”, elkergette magától. A büne elrejtését célzó még nagyobb bün (saját gyermekei megöletésére kiadott parancsa) következményei világos összefüggéseket mutatnak. Mic bán pedig azzal vétkezik, hogy maga is egy nem keresztényi jellegü hit felé fordul, amikor maga kíván a sors menetébe avatkozni, nem bízva ellentétben Ábrahámmal - Isten tetteinek helyénvalóságában. Sőt, a gyermekek elrejtésével, titokban neveltetésével és társadalomba való visszahelyezésüknek a felnőttkorra halasztásával Simon bizonyos szinten a büntető-jutalmazó Istenség szerepét ölti magára. A történéseknek ezt a szintjét, a „Gondviselés müködését” - Orbán László (Uo.) szerint - egyedül Mikhál érzékeli, Simon csak részben, míg Bánk az összeomlás pillanatában jut el eddig a felismerésig: „Nincs a’ teremtésben vesztes, csak én! / nincs árva más több, csak az én gyermekem!” (Bbán Krk., 1983: 300).

Ha nem fogadjuk el, hogy Katona József azért iktatta a Mic bán-epizódot a Bánk bán kidolgozásának második változatába, mert időközben Fesslernél olvasta, hanem tudatos jelentésalkotást feltételezünk az eljárásban - s miért ne tennénk, hiszen Katonának jó dramaturgiai érzéke és színpadi tapasztalata volt -, akkor a lehetséges magyarázatokat - legalábbis részben - a transzcendens térben kell keresnünk. Felfoghatjuk úgy, hogy Simon bán a hetes szám szimbolikájával tulajdonképpen nem a jelen történéseire, nem az ikrek számára utal (ők „egyen felül" vannak, tehát lényegileg mindegy, hogy ketten-e vagy heten), hanem a jövőt vizualizálja. Erre vonatkozhat - a recepció által talányosnak ítélt - belépö mondata: „Hm! Hátha mégis úgy lehetne?” (Uo.: 161). Vagyis - most, hogy nem is egy utódja van - felvirágozhat mégis magyar földön a bojóti nemzetség. Ezt a víziót festi le Mikhálnak - a Spanyol hazába történő visszatérést kilátásba helyező gondolataira reflektálva: ,...elég ha mint meg annyi jó Magyar / Háznépnek ők lehetnek Törzsöki” (Uo.: 163). Ebben a reflexióban az új (erkölcsi) Haza teremtésének ígéretét látjuk felfejleni, sőt, egy második, szimbolikus honfoglalás látomását is beleérthetjük. Ehhez szükséges rituális szám a hetes: a hét vezér-hét nemzetség „törzsöki” analógiája okán. 
Nehéz lenne csak a mintakövetés eljárását, kizárólag elhibázottságot látni a Mic bán-monda drámabeli szerepében, mert ha az is, zseniális „hiba”. Tudjuk, hogy Simon és Mikhál bán, illetve házuk népe merénylet utáni elveszejtéséről semmilyen adat sem maradt fenn a történeti forrásokban, sem a kollektív emlékezet formáiban - a történelmi emlékezet úgy tartja, hogy Gertrudis megöléséért, illetve pártütésért egyedül Töre fia [Töreffy] Pétert, azaz Petur bánt végezték ki. Tudjuk viszont, hogy a mondatípus magyar változatai eredetmondaként lokalizálódtak: több föúri család származtatta magát Simon Micbán hét ikerfiától; többek között a Bocskaiak is, akiknek köréből fejedelmek, azaz uralkodók kerültek ki. Katona József Bánk bán címü drámája ugyan az V. felvonással véget ér, de története a Mic bán-mondákban folytatódik, azaz általuk a dráma virtuálisan ,továbbolvasható”.

\section{IRODALOM}

Badics, F. (1925). Adalékok a Bánk bán történelmi forrásaihoz és irodalmához. Itk, 35, 1-22. Balázs, L. (2012). Rituális szimbólumok a székely-magyar jelképkultúra világából. Csíkszereda: Pallas-Akadémiai Kiadó

Érdujhelyi, M. (1893). Péter és Bánk összeesküvése. Újvidék: Hirschenhauser Benő könyvnyomdája

Csikós, Zs. (1993). A Mic bán-történet irodalmunkban. (Mese és valóság a Bocskai család eredetmondájában), Itk, 97, 1-2., 78 -91.

Dugonics, A. (1788). Etelka, egy igen ritka magyar kis-asszony Világos-várott, Árpád és Zoltán fejedelmek ideikben. Pozsony-Kassa: Füskuti Landerer Mihály betüivel

Fenwick, E. (1993). Kismamák nagykönyve. Budapest: M-érték Kiadó Kft.

Fessler, I. A. (1848). Die Geschichten der Ungern und ihrer Landsassen. 2te Auflage. 2Te Band. Leipzig: Joh. Friedr. Gleditsch.

Heller, B. (1909). Magyar mese- és mondaelemek egyetemesebb kapcsolatban. Ethnographia. A Magyar Néprajzi Társaság értesítője, 20, 65-130.

Katona, J. (1983). Bánk bán (Krk.). Sajtó alá rendezte: Orosz László. Budapest: Akadémiai Kiadó.

Kézai, S. (1782). M. Simonis de Keza Chronicon Hungaricum. Excitat Alexius Horányi. 2. editio. Budae.

Kézai, S. (é.n.) Kézai Simon Mester Magyar Krónikája. Ford. Szabó Károly. http://mek.oszk. hu/02200/02249/02249.htm\#14

Kierkegaard, S. (1986). Félelem és reszketés. Ford. és a jegyzeteket összeállította: Rácz Péter. Budapest: Európa

Orbán L. (2004). Idegenek az éjszakában. Mikhál- és Simon-kommentárok. In: Debreczeni, A. (szerk.) (2004). Tanulmányok a felvilágosodás magyar irodalmáról. A Debreceni Egyetem Magyar és Összehasonlító Irodalomtudományi Intézetének Kiadványa: Studia Litteraria, Tomus XLII., 88-110.

Pór, A. (1890). Bánk bán Melindája. Az Erdélyi Múzeum-Egylet bölcs., nyelv- és tört. tud. szakosztálya kiadványai. VII. k., 491-507.

Pócs, É. (2002): Magyar néphit Közép- és Kelet-Európa határán. Budapest: L' Harmattan

Todorov, T. (2002). Bevezetés a fantasztikus irodalomba. Ford. Gelléri Gábor. Budapest: Napvilág

Tolnai, V. (1918). Katona József és Fessler. Itk, 28, 1-13. 
Waldapfel, J. (1931). A Bánk bán történetéhez. Itk, 41, 385-409.

Waldapfel, J. (é. n. [1942]). Katona József. [Budapest:] Franklin Társulat

White, H. (1997). A történelem terhe. Fordította Berényi Gábor et al. Budapest: Osiris.

\title{
Erika Bence
}

\section{BANK BAN I PITANJE LEGENDE O BANU MICU}

\begin{abstract}
REZIME
Za klasično dramsko delo mađarske književnosti, Ban Bank Jožefa Katone vezuje se poveći opus istorijsko-poetskih, monografskih, arhivskih i folklorističkih istraživanja. Njen značaj i složenu strukturu značenja potvrđuje i činjenica da se i nakon skoro dva veka mogu aktualizirati njene dileme, mogu postaviti do danas diskutabilna pitanja njenog poimanja na koji još nije dat potpun odgovor, a mogu se analizirati i praznine u njenom razumevanju. Ovo naše istraživanje usmereno je na analizu pomenute drame Jožefa Katone, tačnije na epizodu legende o Banu Micu, sa kojom se književna recepcija bavila samo u velikim crtama, i koja je iz dramaturških razloga okvalifikovana kao pogrešan potez pisca. Analiza uključuje u sebi aspekte više odnosnih disciplina, pored književnoistorijskog i aspekt kulturne antropologije. Cilj ovih razmatranje svakako nije rešavanje fundamentalnih problema vezanih za ovu dramu, ali je njena intencija, da kroz interdisciplinarni pristup pospeši razumevanje određenih elemenata ovog dela (npr. funkciju ubacivanja scene o Banu Micu, istorijsku verodostojnost priče o sedam blizanaca bana Šimona, problematiku upotrebe broja sedam itd.)

Ključne reči: legenda o banovici Mic, književne obrade, evropska folklorna književnost, mitska svest, prekobrojnost
\end{abstract}

Erika Bence

\section{BÁNK BÁN AND THE QUESTION OF THE LEGEND ON BÁN MIC}

\section{SUMMARY}

The classic dramatic work in Hungarian literature, Bán Bánk (Viceroy Bánk) by József Katona is closely linked to a vast opus of historical-poetic, monographic, archival and folklore research. Its significance and complex structure of meanings is affirmed by the fact that after nearly two centuries the emerging dilemmas are still topical; issues still relevant to its conception, which have not yet fully been answered, can recurrently be asked; and the gaps in its comprehension can also be explored.

This study deals with the analysis of Katona's quoted drama, more precisely with the episode on Bán Mic's (Viceroy Mic) legend, with which the literary reception has been engaged only in rough lines, and which has, for dramaturgic reasons, been qualified as the author's wrong move. The analysis encompasses aspects of several related disciplines, in addition to literary-historical and culturalanthropological ones. The aim of the discussion is by no means to resolve fundamental problems related to this drama, but its intention is to develop - through interdisciplinary approach - the understanding of certain elements of this work (e.g. the function of including the scene on Bán Mic, the historical credibility of the story of Bán Simon's septuplets, the symbolism of number seven, etc.)

Key words: the legend of Vicereine Mic, European folklore literature, mythical consciousness, supernumerary, legend of origin 